\title{
Institutes of National Remembrance and their Role in Dealing with National Socialism
}

\author{
An Examination of the Issues, Debates and Public Perceptions
}

\begin{abstract}
In the context of debates on recent episodes of national history, specialized archival and research facilities were founded in several countries in EastCentral and Eastern Europe. Often referred to as "Institutes of National Remembrance", they were supposed to dedicate their work to both the communist and National Socialist (occupation) periods. The following chapter explores the debates surrounding the creation of these institutions in Poland, Slovakia and the Czech Republic, as well as their realization and their subsequent activities in dealing with the Nazi period. In terms of the scope of their research activities, their public profile and the degree of meaning that was attached on a political level, work on the archival legacy of the communist state security services significantly overshadowed the way the National Socialist period was dealt with. However, in terms of the way the period 1938/39 to 1945 was remembered, the institutes could also achieve political meaning and public awareness, and thus contribute to a significant commemorative culture, especially in terms of raising questions relating to how the whole of society associates perpetrators and victims within a context of foreign domination and complicity.
\end{abstract}

\section{Introduction}

Following the collapse of the communist system in Central and Eastern Europe at the end of the 1980s and the beginning of the 1990s, debates were held in the former Eastern bloc countries surrounding the way the histories of these nations should be critically examined and processed. Against this backdrop, proponents in favor of critically examining the previous political systems set up specialized state-run archives and research institutions which focused on the recent past. In many cases, this work centered on the socialist systems which had immediately preceded this period and the archives compiled by the former state security services. ${ }^{1}$ The purpose of some of these institutions - often entitled Institutes of $\mathrm{Na}$ -

1 See also Carola Lau: Erinnerungsverwaltung, Vergangenheitspolitik und Erinnerungskultur nach

Ә OpenAccess. ( 2020 Carola Lau, published by De Gruyter. (cc) BY-NC-ND This work is licensed under the Creative Commons Attribution-NonCommercial-NoDerivatives 4.0 License. 
tional Remembrance - was primarily to critically examine the decades between 1938/39 and 1989/90 which therefore included the National Socialist era and period of occupation. Consequently, the political will to focus on the recent past, and particularly the communist past, opened up the potential for the National Socialist era and the Second World War to be re-examined on an institutional basis.

The following essay examines three Institutes of National Remembrance ${ }^{2}$ the Institute of National Remembrance (Instytut Pamięci Narodowej, IPN) in Poland, the Nation's Memory Institute (Ústav pamäti národa, ÚPN) in Slovakia and the Institute for the Study of Totalitarian Regimes (Ústav pro studium totalitnich režimů, ÚSTR) in the Czech Republic. From a comparative perspective, the objective of this essay is to outline the starting position which led to the establishment of the institutes and the debates surrounding their organization. The essay also aims to describe the structure and subsequent activities of the institutes and the role they played in stewarding national historical consciousness, in promoting a culture of remembrance and in shaping policies for dealing with the political past. The analysis will focus on the way the National Socialist era (period of occupation) is dealt with which will be evaluated within the wider debate about the recent past which has taken place in the countries under consideration. It also aims to examine the degree of importance that can be attached to this period when the institutions were being established and later on in terms of their self-perception, and when this might be relevant on a political and public level.

1989 - Institute für nationales Gedenken im östlichen Europa im Vergleich, Göttingen, V\&R unipress, 2017.

2 In the following essay, the title "Institute of National Remembrance" will be used as a generic term for the three institutes that are being examined, even though the Czech institute has a different name. In the Czech Republic, right up until the end of the legislative debate, the institute which finally came to be called the ÚSTR was originally going to be called the 'Institute of National Remembrance' (Ústav paměti národa) to conform with the name given to the institutions that had been previously set up in Poland and Slovakia. The term pamięć (Polish), pamät' (Slovak) and pamět' (Czech) which is used in the Slavic institutes' nomenclature is usually referred to as Gedächtnis (memory) in German. The titles of the above institutions are therefore translated in the literature as the "Institutes of National Memory." However, due to their activities as preservers of a specific memory and through their role of actively promoting a specific type of remembrance, the term "Institute of National Remembrance" is considered to be more accurate for the purpose of this essay. 


\section{The Starting Position}

The Institutes of National Remembrance that are being considered in this essay were established only years after the regime changes in Poland, Slovakia and the Czech Republic. Thus, during the time they were established and developed - in Poland in 1998, in Slovakia in 2002 and in the Czech Republic in 2007 - they were inevitably placed within the context of previous debates on how each nation should deal with their recent pasts. During this period especially, the process of decommunization, otherwise known as lustration, defined the political and public debate on this subject in the Czech Republic and Poland. This refers to the process of purging certain public offices of individuals who were regarded as being tainted by their official or unofficial involvement with the communist intelligence services or, as was the case in the Czech Republic, who were highranking members of the Communist Party. Corresponding laws were enacted to address this issue in both countries during the 1990s. ${ }^{3}$ Highly controversial questions were raised relating to the value and credibility of the records which had been collected under the legacy systems. These questions formed the basis of decisions concerning whether an individual was deemed to be tainted or not by the past. The publication of lists ${ }^{4}$ of individuals who were alleged to be tainted by their past activities was already adding heat to the debate in the Czech Republic back in 1992. It is clear that this was a burning issue in the Czechoslovak Federation and in the following years in the Czech Republic due to the fact that the Office of the Documentation and the Investigation of the Crimes of Communism (Úrad dokumentace a vyšetřování zločinů komunismu, ÚDV) was established in 1995 thanks to the existence of two former institutes that had been

3 In the Czechoslovak Federation, a law had already been passed in 1991 described as the law "On enforcing further conditions relating to the execution of some of the functions in the public bodies and organizations in the Czech and Slovak Federal Republic, the Czech Republic and the Slovak Republic". This was followed in Poland in 1997 by the law "On disclosure of work or service for state security bodies or unofficial cooperation with them in the period between 19441990 by individuals performing public functions."

4 The former dissident and staunch anti-communist Petr Cibulka published the "Cibulka Lists" in 1992 in the magazines Rudé krávo and Necenzurované noviny which specified the names of 160,000 alleged collaborators of the Czechoslovak state security services. The lists had not been officially corroborated and were strongly contested by the accused and many other individuals. 
set up in the Ministry of Interior. The UDV specifically focused on carrying out investigations into crimes committed by state agencies between 1953 and 1989. ${ }^{5}$

After Slovakia had separated from the Czech Republic, it was only at the end of the 1990s, that there was again a greater focus on critically examining the nation's recent past. ${ }^{6}$ This resulted in the parliament enacting laws in 1999 and 2002 which were intended to help arrange compensation for victims who were deported to Nazi concentration camps and prison camps from 1939 to 1945 or settlements for members of the Slovak resistance movement and former political prisoners. ${ }^{7}$ Yet, during 1999, the former Slovak Justice Minister Ján Čarnogurský was unable to push through a law to establish a Slovak institution along the same lines as the Czech UDV. He was only able to set up the Office of the Documentation of the Crimes of Communism at the Justice Ministry of the Slovak Republic (Oddelenie pre dokumentáciu zločinov komunizmu Ministerstva spravodlivosti Slovenskej republiky, ODZK).

During the 1990s in Poland on the other hand, an institution, which had been in existence for quite some time, was widening the scope of its activities to include the critical examination of Stalinist crimes prior to December 31, 1956. This work was carried out from April 1991 by the Central Commission for the Prosecution of Crimes against the Polish Nation - Institute of National Remembrance (Główna Komisja Badania Zbrodni przeciwko Narodowi Polskiemu - Instytut Pamięci Narodowej) whose objective was to gain new insights into the past and start criminal proceedings by using new witness statements and accessing archives that had not been available until that point. ${ }^{8}$ The institution arose from the Central Commission for the Investigation of German Crimes in Poland (Główna Komisja Badania Zbrodni Niemieckich w Polsce) which was founded in

5 The ÚDV continues to exist today as part of the Police of the Czech Republic under the jurisdiction of the Ministry of the Interior. See https://www.policie.cz/clanek/urad-dokumentace-avysetrovani-zlocinu-komunismu-679905.aspx. Last accessed: 6.3.2019.

6 Very little relevant legislation was passed until Prime Minister Vladimír Mečiar was voted out in 1998. The collections of records belonging to the former Slovak state security services had also not been made available at this point. The "Law on the Immorality and Injustice of the Communist Regime", which was approved by the Slovak parliament in 1996, was only really symbolic in nature.

7 A list of all of the laws relating to this theme is available on the ÚPN website: https://www. upn.gov.sk/sk/dokumenty/. Last accessed: 6.2.2019.

8 Witold Kulesza: "Verbrechen im Parteiauftrag als Gegenstand des Strafverfahrens in Polen”, in Dagmar Unverhau and Roland Lucht (eds.): Lustration, Aktenöffnung, demokratischer Umbruch in Polen, Tschechien, der Slowakei und Ungarn, Münster: LIT, 2005, 43-46. 
November 1945. ${ }^{9}$ This was then renamed the Central Commission for the Investigation of Hitlerite Crimes (Główna Komisja Badania Zbrodni Hitlerowskich w Polsce) in $1949 .^{10}$

The main focus of its work at that time was to document and research events that occurred during the war and when Poland was occupied, using witness statements, inspections of crime scenes and disinterments, whereas crimes committed during 1939 to 1941 during the Soviet occupation and German crimes committed in what became the former Polish eastern territories after 1945 were not dealt with. ${ }^{11}$ The Commission acted as an instrument of the Polish government to help determine policies for dealing with the past. It regularly criticized what was alleged to be West German revisionism and referred in positive terms to the efforts that were being undertaken in the GDR to critically examine the past. However, it did work in partnership with Western European and American authorities and with the West German Central Office of the Land Judicial Authorities for Investigation of National Socialist Crimes (Zentrale Stelle zur Aufklärung von NS-Verbrechen) in Ludwigsburg. ${ }^{12}$ During the 1960s, the Commission was part of anti-Zionist campaigns, however, it denied antisemitism in Polish society and the participation of some Polish citizens in the Nazi persecution of the Jews. ${ }^{13}$

In 1984 political decision makers added Institute of National Remembrance to the Commission's title and explicitly mandated the Commission to focus on three key areas: prosecution, archive management and research. ${ }^{14}$ The role of the research department was to develop proposals for educational initiatives ${ }^{15}$ and to shape the idea of Polish national remembrance in a more active way in

9 Council of Ministers of the Republic of Poland, 1945. Decree of November 10, 1945 on the Central Commission and the District Commissions for the Investigation of German Crimes in Poland (Dziennik Ustaw 1945 no. 51 item. 293).

10 Andreas Mix: "Juristische Ermittlungen und historische Forschung in Polen. Von der 'Hauptkommission' zum Institut des Nationalen Gedenkens”, in Wolfgang Benz (ed.): Wann ziehen wir endlich den Schlussstrich? Von der Notwendigkeit öffentlicher Erinnerung in Deutschland, Polen und Tschechien", Berlin: Metropol, 2004, 75-94, here 80.

11 Ibid., 76 and following.; Council of Ministers, 1945, art. 3 b).

12 Mix, 2004, 77 and 81 and following; Kulesza, 2005, 43.

13 Mix, 2004, 85.

14 Council of State of the Republic of Poland: Law of April 6, 1984 on the Central Commission for the Investigation of Hitlerite Crimes - Institute of National Remembrance (Dziennik Ustaw 1984 no. 21 item. 98), art. 2 and art. 9.1.

15 Ibid., art. 5. 
keeping with the Commission's new title. ${ }^{16}$ The epithet Institute for National Remembrance ultimately outlasted the regime change in 1989/1990.

The debates surrounding the establishment of the Institutes of National Remembrance took place in the Czech Republic and Poland within the context of previous controversies that had been fought out in the political and public arenas. After the debates on decommunization or lustration, the situation was now characterized by a desire to regulate the storage and access to the records produced by the state security services. After years of modest activity and influenced by developments in its neighboring countries, political decision makers in Slovakia also became more interested in grappling with their country's recent past. The question of how to deal with the collections of documents from the communist era that could now be accessed had become an extremely delicate matter because only a short amount of time had elapsed since the events under scrutiny had passed. The whole issue was also very sensitive because it had the potential to result in specific consequences for both private individuals and public figures. This could not apply (anymore) to archive collections from previous periods, including those from the National Socialist era (period of German occupation). A critical analysis of communism was now being seen as a higher priority in all three countries, as demonstrated by the drive during the 1990s to institutionalize efforts to re-examine the past by focusing attention on Stalinist and communist crimes through the work of institutions that had recently been set up or former institutions that were realigning their focus. The parliamentary and public de-

16 The first Polish Institute of National Remembrance was initiated in 1944 by the Polish Committee of National Liberation (Polski Komitet Wyzwolenia Narodowego) in Lublin. According to the co-founder of the institute, the author Helena Boguszewska, it was intended that the Institute would focus on, "the martyrdom under the occupation, the struggle against Hitlerism and the reorganization of the political system." See also Helena Boguszewska: Nigdy nie zapomne [I will never forget], Warsaw: Wiedza, 1946, 38. The Institute tried, among other things, to preserve documents and other testimonies from Majdanek concentration camp and, until it was renamed in 1948 and closed in 1950, it devoted much of its efforts to documenting and publishing materials. See Iwona Pachcińska: Władysław Bartoszewski. Doktor Honoris Causa Katolickiego Uniwersytetu Lubelskiego Jana Pawła II [Władysław Bartoszewski. Degree honoris causa from the John Paul II Catholic University of Lublin.]. Lublin, 2008. Available at: http://www.kul.pl/files/254/ bartoszewski_DHC_KUL.pdf. Last accessed: 4.6.2019, 21 and 32. In terms of content, the Institute critically examined German war crimes in Poland, Polish collaboration with the German occupying forces and Polish history from the suppression of the 1863 January Uprising until the end of the Second World War, and therefore specifically the role of the labor movement. It also documented information about concentration camps, places where mass executions had taken place and estimated the extent of Poland's losses due to the war. See Krzysztof Pilawski: "Prawo do pamięci [A Right to Memory]", in: Przegląd, n.d. Available at: https://www.ty godnikprzeglad.pl/prawo-do-pamieci/. Last accessed: 4.6.2019. 
bates surrounding the Institutes of National Remembrance were a natural continuation of this development.

\section{The Process of Establishing the Institutes}

The establishment of a Polish Institute of National Remembrance constituted one of the most important aspects of the work that was being undertaken to process the recent past by the conservative-liberal government during the legislative period from 1997 to 2001. Even though the coalition government had a clear majority in the Sejm (the lower house of the Polish parliament), the decision to establish the institute was accompanied by long and heated parliamentary debates, a declaration by the Senate (the upper house of the Sejm) and a veto by President Aleksander Kwaśniewski ${ }^{17}$ which was finally overruled by the Sejm. The project received a great deal of media attention. It was repeatedly stressed throughout the parliamentary debate that redefining the way the records were managed and accessed should mean that the files formerly created by the intelligence services should no longer be used as a "political tool or a way to blackmail the nation". ${ }^{18}$ Changing the way the files were controlled was intended to sever the "hellish umbilical cord" that existed between the current constitutional intelligence services and the former communist secret police. ${ }^{19}$ The People's Republic of Poland was described by conservative members of the Sejm as an "unlawful state" (państwo bezprawia) and a "totalitarian state" (państwo totalitarne). ${ }^{20}$ Through its work, the new institution was expected to expose crimes perpetrated by the state and reveal "the true face of the communist state." However, members of the SLD party criticized the legally designated terms "communist state" and "communist crimes", and deemed them to be ideological, a

17 Kwaśniewski was a member of the Democratic Left Alliance (Sojusz Lewicy Demokratycznej, SLD) which was one of the successors of the defunct Polish United Workers Party (Poska Zjednoczona Partia Robotnicza, PZPR).

18 “[...] instrument[...] walki politycznej i mechanism [...] zbiorowego szantażu [...]”, from a speech by Marek Siwiec, for a similar argument see the speeches by Jan Lityński and Bogdan Pęk, at the parliamentary debate on 2.4.1998, (first reading), stenographic report, third period of government, session 15, agenda item 14 .

19 “[...] piekielną pępowinę [...]”, speech by Janusz Pałubicki, ibid.

20 Speeches by Jan Lityński, Piotr Żak and Janusz Pałubicki, ibid.

21 “[...] prawdziw[e] oblicz[e] komunistycznego państwa”, speeches by Janusz Pałubicki, Staniław Iwanicki and Piotr Żak, ibid. 
form of propaganda and part of a non-legal language. ${ }^{22}$ The SLD party also proposed that the period that the new institution covered should be extended to incorporate 1918 onwards because this included crimes which had been committed during the Second Polish Republic that needed to be critically examined. The proposal was not successful. ${ }^{23}$ The debate surrounding the way the records should be managed and accessed therefore clearly exemplified the different ways the past activities of both the Polish People's Republic and the Second Polish Republic were being assessed by political parties who were involved in this process.

On the other hand, discussions concerning the way the period of Nazi occupation was evaluated, or at least more detailed references to this era, were not included in the debate. This is despite the fact that the draft legislation stipulated that the Central Commission for the Prosecution of Crimes against the Polish Nation - Institute of National Remembrance should be integrated into the new institute which would mean that the work of the former institute - and especially its work on this period - would be incorporated into the work of the new institute. Ironically, the participants in the parliamentary and public debates which focused on processing Poland's recent past completely obscured the way the Central Commission and the Institute of National Remembrance had evolved before 1989.

The political context from which the preceding institutes arose with its clearly defined political objectives and processes was also not part of the discussions. As the coalition government thought that integrating criminal prosecution, educational activities and archive management into one institution would be appealing and beneficial, they were clearly not interested in critically examining the former institute and its background history when setting up the new institute. The SLD as the successor of the Polish United Workers' Party was also not very interested in critically examining this aspect of the government's project as this would have meant adopting a critical stance towards the institutions that were run during the period of the Polish People's Republic. In December 1998, the Polish Sejm passed the law On the Institute of National Remembrance

22 Speech by Marian Marczewski, ibid.; speeches by Janusz Zemke and Bogdan Lewandowski, debate in the Sejm on 9.9.1998 (2nd reading), stenographic report, third period of government, session 27, agenda item 2.

23 Speech by Katarzyna Maria Piekarska, debate in the Sejm on 9.9.1998 (second reading), stenographic report, third period of government, session 27, agenda item 2. 
and the Commission for the Prosecution of Crimes against the Polish Nation ${ }^{24}$ without having addressed the period between 1939 and 1945 in a more comprehensive way.

Meanwhile in Slovakia in 2001, a group of parliamentarians led by Ján Langoš (who would later become the director of the institute), pressed ahead with passing the law On access to documents compiled by the state security services during the time of oppression from 1939 to 1989 and on the Nation's Memory Institute, an Institute of National Remembrance which was intended to be based on the Polish model (Ústav pamäti národa, ÚPN). Although President Rudolf Schuster vetoed a "package of anti-communist laws"25 and therefore also the UPN law, he was overruled as far as the latter was concerned. Even though media coverage during this period included issues such as the past activities of Slovak judges, or the fact that important state officials used to be members of the Communist Party, it was not focused on uncovering such stories. Moreover, the drafting of the new law did not capture the attention of the media in Slovakia and as a consequence neither the attention of the broader public. ${ }^{26}$ The legislative debate ran relatively smoothly despite the presidential veto and did not feature much in the way of dissent.

However, a large proportion of parliamentarians clearly expressed their opinions about the need for a critical analysis of the past, made a clear assessment of the recent decades of Slovak history and focused the spotlight on crimes that had been committed under the previous systems and on the victims. Langoš provided exhaustive figures relating to the victims of German National Socialism in Slovakia and of Soviet communism in Czechoslovakia from 1939 to 1989 to support his argument that this was an era marked by continuous oppression and a lack of freedom. He clearly defined the period between 1939 and 1989 as a "totalitarian past" (totalitná minulost) which was characterized by "repressive institutions" (represivnych inštitúciú). ${ }^{27}$ It was never really in doubt in parlia-

24 Ustawa z dnia 18 grudnia 1998 r. o Instytucie Pamięci Narodowej - Komisji Ścigania Zbrodni przeciwko Narodowi Polskiemu (Dziennik Ustaw 1998 nr 155 poz. 1016) Tekst ogłoszony [adopted text], hereinafter the IPN Law.

25 Patricia Ďurišková: "Medzi sudcami nad’alej zostanú bývalí tajní [Former secret service agents still working as judges]", in Pravda, 21.8.2002, 1-2, 1.

26 The magazine Kritika \& Kontext described a culture of "silence" that had been ongoing for a number of years in politics, the media, the academic world and among the general public. Miroslav Kusý et al.: "Dedičstvo ŠtB na Slovensku [The legacy of the ŠtB in Slovakia]", in Kritika \& Kontext, 2-3, 29-39.

27 Speech by Ján Langoš, National Council of the Slovak Republic, parliamentary date on 9.7. 2002, stenographic report, period of government 1988 to 2002, session 61 . 
ment that the periods of National Socialism and the People's Republic should both be viewed as a "time of oppression".

Langoš stressed several times that the National Socialist and Bolshevik-communist ideologies were both foreign sets of beliefs that had not originated in Slovakia and that they had been brought into the country by Germany and Russia. ${ }^{28}$ In doing so, he also avoided attributing any responsibility or even guilt to the Slovak people as a whole. Although during the debate Langoš touched upon the Slovak state between 1939 and 1945, and the persecution of the Jewish population in this region, he did not mention Slovak policy makers, their party and affiliated organizations such as the Hlinka's Slovak People's Party and its paramilitary wing, the Hlinka Guard, or the Hlinka Youth. ${ }^{29}$ This was interesting given that leading Slovak players had worked quite separately from Germany towards finding "a solution to the Jewish question". ${ }^{30}$ Even the politician and Roman Catholic priest Jozef Tiso - described a few years later as "our most controversial historical figure" ${ }^{31}$ by a journalist in the magazine Týždeň - was not mentioned by any of the participants in the debate, despite the fact that as a leading politician in the Slovak state ${ }^{32}$ he should have been the focal point of the debates surrounding the way the state was evaluated.

An externalization of responsibility was not only evident in the use of the expression "era of oppression", which already implied that it was impossible for the Slovaks to make any decisions regarding their own degree of responsibility, but could also be seen in the way that the initiator of the law would only refer to the terms "National Socialist" and "communist" and failed to recognize that the Slovak state could be characterized in its own right as having developed from an authoritarian to a totalitarian regime which had some fascist elements. ${ }^{33}$ The parliamentary debate did not prompt an analysis of the Slovak state between

28 Speech by Ján Langoš, National Council of the Slovak Republic, parliamentary debate on 19.8.2002, stenographic report, period of government 1998 to 2002, session 63 .

29 Speech by Ján Langoš, National Council of the Slovak Republic, parliamentary date on 9.7. 2002, stenographic report, period of government 1988 to 2002, session 61.

30 Ivan Kamenec: “The Slovak state, 1939-1945”, in Mikuláš Teich et al. (eds.): Slovakia in History, Cambridge: Cambridge Univ. Press, 2011, 175-192, here 184; Tatjana Tönsmeyer: Das Dritte Reich und die Slowakei 1939-1945. Politischer Alltag zwischen Kooperation und Eigensinn, Paderborn: Schöningh, 2003, 336.

31 Martin Hanus: “Čas na rozsudok [Judgement Time]”, in Týždeň, 29.8.2005, 16-23, 17.

32 Tiso was Prime Minister and President of the Slovak State from 1939 to 1945 and "leader and president” between 1942 and 1945.

33 Ivan Kamenec describes the development of domestic policy in the Slovak state as a development "from an authoritarian regime to totalitarianism with significant fascist elements, but also with several specifically Slovak features.” Kamenec, 2011, 182-183. 
1939 and 1945. This aspect was pushed into the background instead, which was in contrast to the speeches that were made concerning the opening of the archives on the former communist intelligence services. The Slovak Law on National Remembrance was passed in August 2002. ${ }^{34}$

In the Czech Republic, parliamentary debates were repeatedly held for many years regarding the establishment of a new institute that would manage the archives and help to process the nation's recent past. It was envisaged that this institute would bring together documentation, academic research and file collections, foster relationships with other institutions, and enhance public awareness. Draft legislation from 1999 that was connected to this relating to the Memorial to the Era of Oppression 1939 to 1989 (Památník doby nesvobody 1939 to 1989$)^{35}$ and draft legislation relating to the Institute for the Documentation of Totalitarian Regimes (Institut pro dokumentaci totality) ${ }^{36}$ from 2001 basically differed in that it was envisaged that the second bill would limit the institute's activities to the period between 1949 and 1990.

It was not until 2006 that a group of liberal-conservative members of parliament were able to launch an initiative to establish an Institute of National Remembrance (Ústav paměti národa, ÚPN). The most significant change was that the project was intended to reach well beyond previous initiatives in terms of the way the collections of documents relating to the former intelligence services would be managed, making it possible to access the documents in a new and efficient way. ${ }^{37}$ It is also probable that this was influenced by the increasing numbers of revelations in the Czech Republic concerning public figures who were accused of collaborating with the former Czech state security service. ${ }^{38}$ It was also repeatedly discussed in an extremely heated debate whether the entire

34 Act no. 553/2002 of August 19, 2002 entitled "On disclosure of documents on the activities of the state security services from 1939 to 1989, on the establishment of the Slovak Nation's Memory Institute and on the amendment of certain laws”, 553/2002 Z. z.

35 Senate of the Czech Republic, Návrh zákona o Památníku doby nesvobody [draft bill on the Memorial to the Era of Oppression], parliamentary paper 450/0, 1999.

36 Chamber of Deputies of the Parliament of the Czech Republic, Application by the parliamentary members Václav Krása, Marek Benda, Josef Janeček and others relating to the adoption of the law on the Institute for the Documentation of Totalitarian Regimes and the amendment of certain other laws, parliamentary paper 1118-1st reading, session 43, 11.12.2001.

37 Senate of the Czech Republic, Application by the Senate relating to the adoption of the law on the Institute of National Remembrance and the amendment of certain other laws. 21.8.2006, parliamentary paper 15/0.

38 Signatories of Charter 77, and Czech singers and actors, reported unofficial collaboration with the state security service. 
period between 1949 and 1990 that was being examined by the institute could be described as totalitarian.

Criticism was also voiced about the fact that initially the draft bill stipulated that the new institute would only focus on the period between 1948 and $1990 .{ }^{39}$ It was also argued that if the institute also incorporated the period from 1939, it would be in a position to continue the work of the Czech Government Commission for the Prosecution of Nazi War Crimes which had been abolished in $1990 .{ }^{40}$ However, a broader debate was not held on the inclusion of this period of history, or on the activities of the former Commission, despite the fact that this timeframe had been ultimately agreed by consensus by all of the parties involved. The fact that it was being implied that communism and National Socialism were both similar totalitarian systems was also not critically examined by the members of parliament. In June 2007 the law On the Institute for the Study of Totalitarian Regimes, and the Security Services Archive and amendments to certain other laws was enacted. ${ }^{41}$

The debates surrounding the establishment of the Institutes of National Remembrance showed that there was already a clear imbalance with regard to political and public input and the way that this period, which was characterized by communism and National Socialism/fascism, would be dealt with in terms of content. This was undoubtedly because issues that were raised concerning the immediate past and the fiercely debated interpretations of state socialism during these periods were utterly overwhelming. Moreover, this provided a hint of the types of agendas that would be carried out by the new institutions. In addition, aspects which were not being examined at this time, such as the tendency to externalize in the legislative text and the way previous institutions had politicized history, certainly played a key role in the future activities of the institutes. In terms of the suppression of specific historical aspects, it was significant that the origin and historical context relating to the name Institute of National Remembrance, which originated in Poland and was adopted in draft legislation in Slovakia and the Czech Republic, was not the subject of discussion or examined critically in any of the debates at all.

39 Not only the Greens but also the Social Democrats and the Communists supported the idea of extending the timeframe to include 1938 to 1945.

40 Speech by Karel Černý, parliamentary debate on 7.11.2006, Chair of Deputies of the Czech Parliament, Application by the Senate relating to the adoption of the law on the Institute of National Remembrance and the amendment of certain other laws, parliamentary paper 15-1st reading.

41 Zákon ze dne 8. června 2007 o Ústavu pro studium totalitních režimů a o Archivu bezpečnostních složek a o změně některých, Sbírka zákonů Nr. 181/2007. 


\section{Activities Undertaken by the Institutes of National Remembrance}

According to the preamble to the law on the Polish Institute of National Remembrance, the objective of this institute is to preserve the memory of the immense sacrifices, losses and harm suffered by the Polish people during and after the Second World War, to represent the patriotic legacy of the Polish people in their struggle against the occupiers, National Socialism and communism, and to convey the actions of Polish citizens in their attempt to secure an independent Polish state and to defend the ideals of freedom and human dignity. The law also emphasized the commitment that had been made to prosecute crimes against humanity and war crimes, as well as the Polish state's commitment to pay compensation to all victims. The text specifically identified the occupying forces, National Socialism, communism and the machinery of the People's Republic as the "perpetrators" whose crimes should be prosecuted, disclosed and remembered. The law vehemently condemned both the period of German occupation and the People's Republic of Poland along with their ideologies.

The Slovak legislators adopted this wording almost to the letter in the preamble of the Slovak Law on National Remembrance. Only the term "National Socialism" was replaced with the term "fascism". The specific circumstances relating to the years 1939 to 1945 when Slovakia was a "protectorate" of the German Reich were not mentioned, even though this is clearly different to the period of German occupation in Poland which happened at the same time. The expression "era of oppression" that was used to describe the timeframe that would be the focus of the UPN's work reflected once more the tendency to externalize responsibility that had already been part of the parliamentary debates. It set the starting point as April 18, 1939 when the government of the Slovak state passed the first legislation known as the "Jewish Laws" which marginalized Jewish citizens. However, the law does not name any leading figures who passed laws such as the Decree of April 18, 1939 and the parties and organizations of this state whilst it examines the departments of the state security services from the 1940s in greater detail..$^{42}$

42 The way $\S 8$ of the law is worded, which emphasizes that the ÚPN should judge the "participation of native and foreign individuals" in the fascist and communist system, does very little to attenuate this impression. As has already been stated, this is especially relevant given that specific National Socialist and fascist organizations are not mentioned throughout the entire legislative text. 
The preamble of the Czech law on the Institute for the Study of Totalitarian Regimes also describes the twentieth century as an era that is marked by two totalitarian regimes and their communist and National Socialist ideologies. It identifies two key periods in which human rights were suppressed and democratic principles were violated: The "era of oppression" between 1938 and 1945 and the "period of totalitarian communist rule" from 1948 to 1989. In using the words "totalitarian and authoritarian regimes of the 20th century" the law is referring to the criminal organizations that followed communist and National Socialist ideologies in equal terms and it therefore treats National Socialism and communism as part of the same continuum of totalitarian rule.

In its preamble, the law clearly refers to preceding projects that have already been described in which accounts of the consequences of the regimes especially, from the violation of human rights to the destruction of nature, can also be found in an almost identical form. The legislators referred here to the Czech Law on the Illegitimacy of the Communist Regime that was enacted in 1993. It is therefore not surprising that the statements in the law relating to the USTR appear to be more relevant for the Czechoslovak Socialist Republic than for the period between 1938 and 1945. Despite explicitly mentioning both regimes and ideologies, the law clearly aligns with statutory regulations that had been put in place since the first half of the 1990s in the Czech Republic to tackle the subject of the country's communist past. References to the period of German occupation between 1938 and 1945 look like they were added later, which corresponds with the way in which the parliamentary debates actually progressed.

The three institutes therefore had a broadly defined remit which encompassed archiving and providing access to documents, carrying out research and public relations, and assisting with the prosecution of criminal offenses. The Polish IPN stood apart from the others in that it had its own department, the Central Commission for the Prosecution of Crimes against the Polish Nation (Główna Komisja Ścigania Zbrodni przeciwko Narodowi Polskiemu), which had the legal powers to initiate criminal proceedings and to prosecute. In 2007 the IPN was also mandated to carry out a fourth function which involved dealing with lustration procedures in what was called the Lustration Bureau (Biuro Lustracyjne)..$^{43}$ Meanwhile, a Witness Office was set up at the ÚPN in Slovakia and a Working Group for Oral History was established at the USSTR in the Czech Republic. The Security Services Archive (Archiv bezpečnostních složek, ABS) was unique to the Czech Republic and reported directly into the ÚSTR. It still had its own

43 For further information on the structure of the IPN, refer to the institute's website at https:// ipn.gov.pl/pl/o-ipn/struktura/36493,Struktura.html. Last accessed: 4.6.2019. 
remit with regard to providing access to and publishing documents whereas a department responsible for digitizing archive material was again directly attached to the ÚSTR. ${ }^{44}$

In line with the goals that had already been set out during the legislative debates in all three countries, the institutes were first and foremost expected to take ownership of the documents compiled by the former state security services and make them accessible to the public. The fact that control over the archives was held by civil institutions and not institutions that were connected to the current state security services was particularly important for legislators in Poland and in Slovakia. In 2005 the IPN in Poland finally took over the "[...] biggest archive operation in the history of Poland and perhaps in the whole of Europe". ${ }^{45}$ This is how a former employee described this project which involved the transfer of over 80 kilometers of files into the archives. The UPN in Slovakia had to enforce its legal rights over the Slovak security services and the Czech Republic when taking over the relevant archive materials, ${ }^{46}$ finally acquiring over 1.8 kilometers of records in paper form and on microfiche. By contrast, it was much quicker and easier for the USSTR in the Czech Republic to acquire the 18 kilometers or so of records during 2007 and $2008 .{ }^{47}$

In all three countries the majority of the archive collections came from the former communist intelligence services, which were compiled from the current Department of the Interior, the Defense Department and the Department of Justice. These documents were what made the institutes unique now they were accessible for the first time in this format for research and for use by the general public. Even though discussions surrounding the credibility, comprehensiveness and fundamental significance of the former state security service files have never

44 For further information on the structure of the USTR, refer to the institute's website at https://www.ustrcr.cz/o-nas/organizacni-struktura/. Last accessed: 4.6.2019.

45 "To była największa operacja archiwalna w dziejach Polski, a kto wie, czy nie całej Europy.” Antoni Dudek: Instytut. Osobista historia IPN [The Institute. A Personal History of the IPN], Warsaw: Wydawnictwo czerwone i czarne, 2001, hereinafter: Dudek, 2011, 94.

46 Ústav pamäti národa (eds): Výročná správa o činnosti 2003 [Annual Activity Report 2003], Bratislava. Available at: http://www.upn.gov.sk/data/upn-vyrocna-sprava-2003.pdf. Last accessed: 4.6.2019, 12. ÚPN: "Institut des nationalen Gedenkens - Slowakei”, in BStU (ed.): Das "Europäische Netzwerk der für die Geheimpolizeiakten zuständigen Behörden.” Ein Reader zu ihren gesetzlichen Grundlagen, Strukturen und Aufgaben, Berlin, 74-83, 78.

47 Ústav pro studium totalitních režimů (ed.): Výroční zpráva Ústavu pro studium totalitních režimů za rok 2007 [2007 Annual Report of the Institute for the Study of Totalitarian Regimes], Prague. Available at: http://www.ustrcr.cz/data/pdf/uredni-deska/zprava2007.pdf. Last accessed: 4.6.2019, 6 . 
abated ${ }^{48}$ and the newly established institutes were criticized for their lack of transparency when opening up the collections of records, ${ }^{49}$ the archives undoubtedly provided the first ever opportunity to carry out systematic academic research on the structures, mechanisms and employees of the former state security services. ${ }^{50}$ Although both periods under assessment were mentioned in the legal preambles, the fact that the work carried out by the institutes focused on the activities of the state security services was to all intents and purposes a logical outcome.

By contrast, considerably less attention was given to document collections that related to the period before 1945 , which is certainly due to the fact that these collections were smaller in size ${ }^{51}$ and were not perceived to be as current. However, they also had far less potential to be used in a way that would unleash a scandal. Whereas exhibitions to raise public awareness were conceived that focused on the people who were presumed to have worked full-time and on an informal basis for the communist intelligence services, ${ }^{52}$ potentially scandalous lists were circulated and public figures were held accountable for their words and actions, ${ }^{53}$ there were no discussions in the political and public arenas

48 "Dôverníci o spolupráci vediet' nemuseli [Employees responsible for confidential information would not have known they were collaborating]", in Sme, 21.10.2002, 3.

49 The IPN in Poland was criticized because it is said that a clear succession of people consulted the files and external academics were the last to be granted access. See Dudek, 2011, 79-80. It was only in 2012 that the IPN also published an inventory on its website that included more detailed information on individual documents.

50 Antoni Dudek and Andrzej Paczkowski: "Polen" in Łukasz Kamiński (ed.): Handbuch der kommunistischen Geheimdienste in Osteuropa 1944-1991, Göttingen: Vandenhoeck und Ruprecht, 2009, 265-339, here 330.

51 See also the detailed information on the structure and scope of the archive collections on the websites of IPN: https://ipn.gov.pl/pl/archiw/zasob/31615,Zasob-archiwalny-Instytutu-PamieciNarodowej.html; UPN: https://www.upn.gov.sk/archivne-fondy/klasifikacna-schema.php; and ÚSTR or ABS: https://www.abscr.cz/fondy-a-pomucky/pruvodce-po-fondech-sbirkach/\#schema. Last accessed: 4.6.2019.

52 In 2006 the IPN in Poland arranged a series of exhibitions entitled "Twarze bezpieki" (Faces of the Stasi) which examined the people behind the regional structures of the former state secret services. The exhibitions run by the Institute included photos and information relating to individuals who worked as full-time staff. They were shown in many Polish towns and cities. The ÚSTR in the Czech Republic also organized an exhibition along the same lines called "Tváře moci" (Faces of Power).

53 For example, reference was made to the debates surrounding Lech Wałęsa's collaboration with the communist secret police in Poland, the allegations against Milan Kundera in the Czech Republic and the Wildstein List in Poland which was published by the journalist Bronisław Wildstein in 2005. The List contained approximately 240,000 names linked to former agents, unofficial employees and "operational contacts" of the state security services, and peo- 
about the archive collections that related to the role individuals played in the National Socialist and fascist regimes. Within the institutes there was only a minor scandal at the IPN in Poland when it became clear that its predecessor had sent and consequently lost a large number of original documents to predominantly foreign agencies, including the Central Office of the Land Judicial Authorities for Investigation of National Socialist Crimes in Ludwigsburg. An investigatory commission at the IPN ascertained that over 6,900 documents had been lost, of which there were no copies in Poland, ${ }^{54}$ and finally referred the case to the public prosecution authorities. However, the department of prosecution, after three years in 2009, dropped the case..$^{55}$

Despite the lack of public attention, the institutions' work relating to the period before 1944/45 became more visible in terms of investigative work, publishing information, and running research and educational programs. Even though there was considerably more focus on the period after 1945 in the institutes' own journals, monographs, anthologies, memoirs, films and exhibitions, the period between 1938/39 and 1945 was also covered. A research department was set up at the USTR in the Czech Republic to focus on the period between 1938 and 1945 which, among other things, researched and published materials relating to issues such as political repression and resistance during the period of occupation in the protectorate of Bohemia and Moravia, the prison system between 1938 and 1989 and resistance and persecution of Christians under National Socialism and communism from 1939 to $1989 .{ }^{56}$ In terms of the disclosure of victims and "heroes" of the Czech Republic's recent past, as well as documenting the names of people who were executed due to political reasons, who died in prison

ple who were also alleged to have been recruited as informants although they had never given their consent.

54 Instytut Pamięci Narodowej (ed.): Informacja o działalności Instytutu Pamięci Narodowej Komisji Ścigania Zbrodni przeciwko Narodowi Polskiemu w okresie 1 stycznia 2008 r.-31 grudnia $2008 \mathrm{r}$. [Information relating to the activities of the Institute of National Remembrance - Commission for the Prosecution of Crimes against the Polish Nation from January 1, 2008 to December 31, 2008], Warsaw. Available at: https://ipn.gov.pl/pl/o-ipn/informacje-o-dzialalnos/24314,w-okre sie-1-stycznia-2008-r-31-grudnia-2008-r.html. Last accessed: 4.6.2019.

55 Instytut Pamięci Narodowej (ed.): Informacja o działalności Instytutu Pamięci Narodowej Komisji Ścigania Zbrodni przeciwko Narodowi Polskiemu w okresie 1 stycznia 2009 r.-31 grudnia 2009 r. [Information on the activities of the Institute of National Remembrance - Commission for the Prosecution of Crimes against the Polish Nation from January 1, 2009 to December 31, 2009], Warsaw, 33. Available at: https://ipn.gov.pl/pl/o-ipn/informacje-o-dzialalnos/24313,w-okresie-1stycznia-2009-r-31-grudnia-2009-r.html. Last accessed: 4.6.2019.

56 See also the ÚSTR website at https://www.ustrcr.cz/uvod/doba-nesvobody-1938-1945/. Last accessed: 4.6.2019. 
and who died trying to cross national borders between 1948 and 1989, the USSTR also chronicled the names of Czechoslovakians who were executed at Plötzensee Prison in Berlin and at Pankrác Prison in Prague by the Gestapo during the Second World War. ${ }^{57}$

Of the three countries being examined, only the Central Commission for the Prosecution of Crimes against the Polish Nation in Poland has been able to carry out investigative work and has been directly involved in criminal proceedings. From 2006 it focused on crimes perpetrated after 1956 when the public prosecutors based there had first given priority to the Stalinist crimes. ${ }^{58}$ In keeping with the IPN law's focus on "National Socialist crimes" (zbrodnie nazistowskie), starting with the invasion of Poland by the German Wehrmacht on September 1, 1939, the Central Commission also turned its attention to the murder of Jewish citizens, the abuse of detainees, the execution of resistance fighters by the Gestapo, deportations into the General Governorate (the German zone of occupation established after the invasion of Poland), torture and abuse in forced labor camps, the execution of members of the Polish Home Army, the liquidation of ghettos on Polish territory and mass murder that was carried out there, mass executions of Polish citizens, the murder of patients in psychiatric institutions and forced labor within the territory conquered by the Third Reich. ${ }^{59}$ In 2004 the IPN initiated the international search for twelve perpetrators of "National Socialist crimes" through Interpol. ${ }^{60}$ It investigated crimes committed by the Wehrmacht

57 Ústav pro studium totalitních režimů (ed.): Výroční zpráva Ústavu pro studium totalitních režimů za rok 2008 [2008 Annual Report of the Institute for the Study of Totalitarian Regimes], Prague. Available at: http://www.ustrcr.cz/data/pdf/uredni-deska/zprava2008.pdf. Last accessed: 4.6.2019, 28 and following. See also the ÚSTR website at https://www.ustrcr.cz/uvod/ popraveni-plotzensee/ and https://www.ustrcr.cz/uvod/pankracka-sekyrarna/. Last accessed: 4.6.2019.

58 Instytut Pamięci Narodowej (eds.): Informacja o działalności Instytutu Pamięci Narodowej Komisji Ścigania Zbrodni przeciwko Narodowi Polskiemu w okresie 1 stycznia 2007 r.-31 grudnia 2007 r. [Information on the activities of the Institute of National Remembrance - Commission for the Prosecution of Crimes against the Polish Nation from January 1, 2007 to December 31, 2009], Warsaw, 15. Available at: https://ipn.gov.pl/pl/o-ipn/informacje-o-dzialalnos/24313,w-ok resie-1-stycznia-2009-r-31-grudnia-2009-r.html. Last accessed: 4.6.2019.

59 Instytut Pamięci Narodowej (ed.): Informacja o działalności Instytutu Pamięci Narodowej Komisji Ścigania Zbrodni przeciwko Narodowi Polskiemu w okresie 1 lipca 2000 r.-30 czerwca $2001 \mathrm{r}$. [Information on the activities of the Institute of National Remembrance - Commission for the Prosecution of Crimes against the Polish Nation from July 1, 2000 to June 30, 2001], Warsaw, 33 and following. Available at: https://ipn.gov.pl/pl/o-ipn/informacje-o-dzialalnos/24321,w-ok resie-1-lipca-2000-r-30-czerwca-2001-r.html. Last accessed: 4.6.2019.

60 Instytut Pamięci Narodowej (ed.): Informacja o działalności Instytutu Pamięci Narodowej Komisji Ścigania Zbrodni przeciwko Narodowi Polskiemu w okresie 1 lipca 2003 r.-30 czerwca 
in Poland which were not classed as war crimes by German investigative authorities but as crimes carried out as part of the resistance struggle which led to the proceedings being halted in Germany. ${ }^{61}$ And it achieved some success in repealing judgments that had been reached by German special courts against Polish citizens during the period of German occupation by the German public prosecution authorities. ${ }^{62}$ From the start of its investigatory work, the Central Commission cultivated a working relationship with the German Central Office of the Land Judicial Authorities for Investigation of National Socialist Crimes and other foreign investigative and prosecuting bodies. ${ }^{63}$

The investigative work carried out by the IPN also meant that historical materials could be processed and previously unknown testimonies obtained and used as the basis of academic research and publishing activities relating to the cases in question. ${ }^{64}$ IPN public prosecutors interviewed 600 witnesses about the forced displacement of approximately 20,000 Poles from the area around the town of Żywiec by German occupiers at the end of 1940 during what was called Action Saybusch, and handed over the collection of documents relating to the investigations to the Public Education Office at the IPN where it was used to form the basis of a publication. ${ }^{65}$ The institute's references to the

2004 r. [Information on the activities of the Institute of National Remembrance - Commission for the Prosecution of Crimes against the Polish Nation from July 1, 2003 to June 30, 2004], Warsaw, 9. Available at: https://ipn.gov.pl/pl/o-ipn/informacje-o-dzialalnos/24318,w-okresie-1-lipca-2003-r30-czerwca-2004-r.html. Last accessed: 4.6.2019.

61 Instytut Pamięci Narodowej (ed.): Informacja o działalności Instytutu Pamięci Narodowej Komisji Ścigania Zbrodni przeciwko Narodowi Polskiemu w okresie 1 lipca 2002 r.-30 czerwca $2003 r$. [Information on the activities of the Institute of National Remembrance - Commission for the Prosecution of Crimes against the Polish Nation from July 1, 2002 to June 30, 2003], Warsaw, 36. Available at: https://ipn.gov.pl/pl/o-ipn/informacje-o-dzialalnos/24319,w-okresie-1-lipca2002-r-30-czerwca-2003-r.html. Last accessed: 4.6.2019.

62 IPN, 2004, 9.

63 Instytut Pamięci Narodowej (ed.): Informacja o działalności Instytutu Pamięci Narodowej Komisji Ścigania Zbrodni przeciwko Narodowi Polskiemu w okresie 1 lipca 2001 r.-30 czerwca $2002 r$. [Information on the activities of the Institute of National Remembrance - Commission for the Prosecution of Crimes against the Polish Nation from July 1, 2001 to June 30, 2002], Warsaw, 8. Available at: https://ipn.gov.pl/pl/o-ipn/informacje-o-dzialalnos/24320,w-okresie-1-lipca-2001r-30-czerwca-2002-r.html. Last accessed: 4.6.2019.

64 IPN, 2004, 10.

65 Instytut Pamięci Narodowej (ed.): Informacja o działalności Instytutu Pamięci Narodowej Komisji Ścigania Zbrodni przeciwko Narodowi Polskiemu w okresie 1 lipca 2004 r.-31 grudnia $2005 r$. [Information on the activities of the Institute of National Remembrance - Commission for the Prosecution of Crimes against the Polish Nation from July 1, 2004 to December 31, 2005], Warsaw, 50. Available at: https://ipn.gov.pl/pl/o-ipn/informacje-o-dzialalnos/24317,w-okresie-1lipca-2004-r-31-grudnia-2005-r.html. Last accessed: 4.6.2019. Popular academic literature written 
positive outcomes of its investigative work regardless of any actual convictions, make it even more obvious that both the institute and the Central Commission were always acutely aware of their limited success in the area of criminal prosecutions. This unquestionably related to the advancing years of the victims and perpetrators from the period of German occupation and the Stalinist era. The Ostatni Swiadek (The Last Witness) campaign initiated by the IPN in 2012 appealed for elderly citizens to provide the IPN with information about possible crimes committed against the Polish population. In many instances it was presumed this would be the last opportunity to at least document these types of cases and perhaps make them public, even if it was not possible to carry out criminal proceedings.

One of the most important cases processed by the IPN, which was to profoundly shape the perception of the institute in Poland and abroad when it first started its work, were the investigations carried out by the Central Commission into the Jedwabne pogrom. The case concerned the massacre of Jewish residents in the town of Jedwabne in 1941 by fellow Polish citizens. Staff at the IPN analyzed the case files from 1949 and 1953, questioned witnesses in Poland and Israel and arranged disinterments in Jedwabne. ${ }^{66}$ The institute established that at least 340 Jewish citizens were murdered or burned alive by their Polish fellow countrymen whilst German troops were present in the area. It also underscored the fact that these events were not unique. The subsequent public debates in Poland resulted in a comprehensive study by the $\mathrm{IPN}^{67}$ and an emotionally charged debate across society and in the political arena surrounding the emphasis that is given to historical events in terms of the way the Polish see themselves and define their past, ranging from a "monumental history" to a "critical history" and from a "history of national glory" to "a history of national shame". ${ }^{68}$ Alongside its publishing activities, the institute also undertook measures to increase public awareness. Seminars were organized for school students and teachers from the

by Mirosław Sikora and Monika Bortlik-Dźwierzyńska was published in 2010: Aktion Saybusch. Wysiedlenie mieszkańców Żywiecczyzny przez okupanta niemieckiego 1940-1941 [Action Saybusch. The Displacement of the Citizens from the Żywiec Region Through the German Occupation 1940-1941], the author explicitly refers to the testimonies of hundreds of victims and witnesses that were collected and used as sources by the IPN District Commission in Katowice.

66 IPN, 2001, 10-11.

67 Paweł Machcewicz and Krzysztof Persak (eds.): Wokót Jedwabnego [About Jedwabne], Warsaw: IPN, 2002.

68 Andrzej Nowak: "Westerplatte oder Jedwabne”, in Ruth Henning (ed.): Die "Jedwabne-Debatte" in polnischen Zeitungen und Zeitschriften. Dokumentation, Potsdam: Deutsch-polnische Gesellschaft Brandenburg, 2002, 354-357, here 355; Paweł Machcewicz: "Westerplatte und Jedwabne”, in ibid., 358-361. 
Jedwabne region ${ }^{69}$ and the institute worked with the Auschwitz-Birkenau Memorial and Museum and the Yad Vashem Holocaust Memorial to compile information on thousands of Polish citizens who were murdered or had to suffer repression during the Second World War because they helped their fellow Jewish countrymen. ${ }^{70}$ The institute wanted to use its internet portal entitled "A Life for a Life" to work against what was perceived as a one-sided view of Polish-Jewish relations which presented the Poles as perpetrators and Jews as victims. ${ }^{71}$ The question of guilt surrounding the Holocaust is even to this day seen as a serious and delicate matter. This is demonstrated by the campaign initiated by the IPN already some years ago to challenge the international media's use of the expression "Polish concentration camps" which inferred that the camps had been set up by Poles. In the same context, in 2018, an amendment to the act on the IPN was signed into law in order to protect Poland's reputation. ${ }^{72}$

The way the IPN tackles this difficult chapter in Polish history and PolishJewish relations therefore demonstrates that even in a period of the recent past that was not overshadowed by the communist regime there were issues that awaited scrutiny, and questions raised about responsibility which could be seen to be of enormous current relevance. It also underscores the balancing act that the Institutes of National Remembrance must perform between academic research and often prescriptive educational work, especially when considering questions concerning the roles of victims and perpetrators. The fact that the IPN branch office in Białystok abandoned investigations concerning the events in Jedwabne in 2004 because it was not possible to identify any perpetrators who had not already been convicted in previous trials, ${ }^{73}$ underlines how much importance can also be attributed to these kinds of questions beyond matters relating to criminal prosecutions. The general impact of the research findings was ultimately more modest by comparison which is reflected in the results of the surveys that were conducted when the major public debate was held in 2001: The majority of people surveyed said that they had heard of the events in Jed-

69 IPN, 2001, 71-72.

70 IPN, 2008, 10.

71 Dudek, 2011, 283-284. The portal can be accessed at http://zyciezazycie.pl/. Last accessed: 4.6.2019.

72 The amendment to the law initially criminalized undermining the reputation of Poland, threatening a possible prison sentence of up to three years, however, this was toned down following international protest.

73 Instytut Pamięci Narodowej - Oddziałowa Komisja Ścigania Zbrodni przeciwko Narodowi Polskiemu w Białymstoku: Postanowienie o umorzeniu śledztwa [Decision on the Cessation of Investigations], S1/00/Zn, Białystok: IPN, 2003. 
wabne and were aware that Jewish citizens had been the victims. ${ }^{74}$ However, only part of those surveyed were aware of the key observation from the debate on Jedwabne, namely the fact that Polish citizens acted as perpetrators in this and similar cases. ${ }^{75}$

The ÚPN in Slovakia was not able to carry out its own independent investigations or lustration processes. It could only initiate criminal proceedings by collecting relevant material and handing it over to the public prosecutors. It focused especially on deaths in custody and border deaths before 1989, but this did not lead to criminal convictions. ${ }^{76}$ This, the disclosure of information relating to groups of perpetrators and victims via registers and lists played an even more important part in how the ÚPN saw its role. In addition to registration protocols, which included information on official and unofficial employees of the Czechoslovak state security service or on officials from the Communist Party, the institute published information on the closure and "aryanization" of Jewish businesses, on the commanders of the Hlinka Guard, on the Jewish population in Slovakia in 1942 and on people who were deported to gulags. ${ }^{77}$ Culpable organizations, such as the Hlinka Guard, and Jewish citizens who were persecuted between 1939 and 1945 were now also specifically named. The complexities of Slovakia's recent past are demonstrated in the way Slovak citizens who died fighting in conflicts with the Soviet Union when the Slovak state was an ally of the German Reich are presented by the ÚPN. They are regarded as a group of victims, similar to Jewish citizens who were persecuted by the same state.

In Slovakia, however, lists which focused on the period after 1945 and unofficial employees of the former state security services garnered considerable public interest as well. The involvement of Slovak priests in the former system particularly generated a great deal of interest in the media. The work of the UPN was therefore the focus of attention in two respects; first, because it dealt with the period when the cleric Tiso governed the Slovak Republic and therefore with the degree of influence and accountability prominent church officials had in issues such as the deportation of Jewish citizens. Second, on the publication of the

74 CBOS (ed.): Polacy wobec zbrodni w Jedwabnem - Prezmiany spotecznej świadomości [The Poles Response to the Crimes in Jedwabne - Shifts in Social Attitudes], BS/120/2001, 2.

75 In September 2001, 30 percent of those surveyed could not specify who the perpetrators in Jedwabne were. Ibid.

76 Ústav pamäti národa (ed): Výročná správa o činnosti 2007 [2007 Annual Activity Report], Bratislava, 28. Available at: http://www.upn.gov.sk/data/upn-vyrocna-sprava-2007.pdf. Last accessed: 4.6.2019, 28; see also written statements by the ÚPN to the author dated 22.7.2014. 77 All registers and lists can be accessed via the ÚPN website at https://www.upn.gov.sk/. Last accessed: 4.6.2019. 
state security service records, reference was also made to the priests in various categories and in some cases they were also identified as being collaborators. The public debate surrounding the extent to which these and other individuals acted as unofficial collaborators, which also resulted in libel lawsuits against the UPN, ${ }^{78}$ significantly overshadowed the disclosure of other groups of victims and perpetrators, and other activities that were being undertaken by the UPN. However, this was a deliberate strategic approach on the part of the institute. The UPN hoped to use these kinds of disclosures to initiate a kind of voluntary lustration process within the affected Slovak authorities and institutions without there being an explicit lustration law in place. ${ }^{79}$

\section{Conclusion}

Activities undertaken by the Institutes of National Remembrance in Poland, Slovakia and the Czech Republic formally focused on framing both the National Socialist/fascist and the period of state socialism as repressive systems to the same degree. However, as far as political and public perception was concerned, the prime focus was on the communist period. Most notably, in terms of the scope of their research activities, their public profile and the degree of meaning that was attached on a political level, their work on the archival legacy of the communist state security services significantly overshadowed the way the National Socialist period (period of occupation) was dealt with after 1989. This was due to the fact that, undeniably, concerning the communist period there was a lack of research and because it was now easier to access the source materials on this period.

However, this should be understood in light of the type of approach the institutes took to clarifying specific issues, especially in relation to the communist state security services. Activities related to the political past undertaken by the institutes - often in the form of lists - which focused on inclusion and exclusion through defining groups of heroes, victims and perpetrators, left very little gray areas when it came to individual guilt and involvement. Although relevant lists

78 Ústav pamäti národa (ed): Výročná správa o činnosti 2012 [2012 Annual Activity Report], Bratislava, 11. Available at: http://www.upn.gov.sk/data/upn-vyrocna-sprava-2003.pdf. Last accessed: 4.6.2019.

79 See also the comments made by the first Chair of the ÚPN Ján Langoš in Nadya Nedelsky: “Czechoslovakia and the Czech and Slovak Republics”, in Lavinia Stan (ed.): Transitional Justice in Eastern Europe and the Former Soviet Union. Reckoning with the Communist Past, London and New York: Routledge, 2009, 37-75, 55-56. 
on the period between 1938/39 and 1945 also existed, they received far less public attention, supposedly because they were not seen to be as relevant and topical. The work of the Institutes of National Remembrance on the period of German occupation and the Second World War therefore appears to have been dealt with in an almost dispassionate way, even though this period of history in these countries was continuously processed in the form of infinite lists, and research and educational work.

Nevertheless, the institutes' work on the National Socialist/fascist period achieved political importance and was able to raise public awareness, especially in terms of raising questions relating to how the whole of society associates perpetrators and victims within a context of foreign domination and complicity. The debate in Poland surrounding Jedwabne clearly shows how the institute could certainly fracture views equally across the whole of society concerning the status of victims, perpetrators and heroes, but could then also contribute towards a renewed sense of self-assurance. In terms of the way the period 1938/39 to 1945 is remembered, the institutes could and can therefore try to shape significantly the commemorative cultures of their countries. Apparently, a broader level of public awareness requires to fathom controversies in areas of apparent consensus. However, it is questionable whether this would be helpful when considering the legitimate academic research and long-term educational activities carried out by the institutes. The self-perception of the Institutes of National Remembrance with their investigative and political drive relates primarily to the communist period - as could already be seen during the parliamentary debates. In the end, exactly this factor could have a positive impact on the way these institutions deal with the National Socialist/fascist period in their work. 